\title{
ARTICLES
}

Submitted 06.27.2016. Approved 01.16.2017

Evaluated by double blind review process. Scientific Editor: Martin Jayo

DOI: http://dx.doi.org/10.1590/So034-759020170405

\section{THE USE OF CASE STUDIES IN UNDERGRADUATE BUSINESS ADMINISTRATION}

\author{
Uso de estudos de caso em cursos de graduação em Administração de Empresas \\ El uso de casos en Administración de Empresas a nivel de licenciatura
}

\begin{abstract}
We develop constructs to evaluate the factors influencing the degree of students' acceptance of cases. In our proposed framework, student acceptance is affected by the case selection, intensity of faculty use, training, course type and level, level of instructor expertise, teaching atmosphere, and the faculty's beliefs about the usefulness of the case method. Our sample includes faculty teaching quantitative or qualitative courses across several disciplines in undergraduate business administration. Responses to a survey are analyzed using factor analysis and regression. The quantitative analysis is complemented by interviews with a subset of expert faculty using a two-round modified Delphi technique. This study may be limited by the fact that it measured faculty perceptions of the degree of students' acceptance of cases, rather than student acceptance directly. Future research might survey students or use students' courses evaluations to validate or contradict our results.
\end{abstract}

KEYWORDS | Case teaching in business, undergraduate management education, factor analysis, quantitative and qualitative research, modified Delphi technique.

\section{RESUMO}

Desenvolvemos construtos para avaliar os fatores que influenciam o grau de aceitação dos alunos em relação aos estudos de casos. Na configuração proposta, a aceitação dos alunos é afetada pela seleção do caso, intensidade de seu uso pelos docentes, formação, tipo e nível do curso, nível de especialidade do instrutor, atmosfera de ensino, e crenças dos docentes com relação à utilidade do método de estudo de caso. Nossa amostra inclui docentes de cursos quantitativos ou qualitativos em várias disciplinas em nível de graduação na área de administração de empresas. As respostas à pesquisa foram analisadas utilizando-se análise fatorial e regressão. A análise quantitativa é complementada por entrevistas com um subconjunto de docentes especialistas, utilizando-se uma técnica Delphi de dois ciclos modificada. Este estudo pode ser limitado pelo fato de haver mensurado percepções de docentes quanto ao grau de aceitação de alunos em relação a estudos de casos, e não a aceitação dos alunos diretamente. Futuros estudos podem pesquisar alunos ou utilizar avaliações dos alunos com relação aos cursos para validar ou refutar nossos resultados. PALAVRAS-CHAVE / Ensino de caso em negócios, graduação em Administração de Empresas, análise fatorial, pesquisa quantitativa e qualitativa, técnica Delphi modificada.

\section{RESUMEN}

Desarrollamos constructos para evaluar los factores que influyen en el nivel de aceptación de los estudiantes en relación a los casos de estudio. En el marco conceptual que proponemos, la aceptación del estudiante se determina por la selección de los casos, la intensidad de uso por parte de los profesores, el entrenamiento, el tipo y nivel del curso, la experiencia de los profesores, la atmósfera de enseñanza, y la convicción del cuerpo docente sobre la utilidad del método de casos. Nuestra muestra incluye profesores de cursos cualitativos y cuantitativos de varias asignaturas de la licenciatura de administración de empresas. Las respuestas de la encuesta se analizan a través de análisis factorial y análisis de regresión. El análisis cuantitativo se complementa con entrevistas a profesores expertos; y una parte de la muestra, mediante el método Delphi modificado en dos rondas. Una posible limitación del estudio es el hecho de que medimos la percepción de los profesores sobre el nivel de aceptación de los estudiantes, en vez de medir directamente el nivel de aceptación de los estudiantes. Futuros trabajos de investigación podrían encuestar a estudiantes o usar evaluaciones de estudiantes acerca de cursos con casos para validar o contradecir nuestros resultados.

PALABRAS CLAVE / Enseñanza a través del método de casos en negocios, licenciatura en administración de empresas, análisis factorial, investigación cuantitativa y cualitativa, método Delphi modificado. 


\section{INTRODUCTION}

Business schools use case studies extensively (Burgoyne \& Mumford, 2001; Ambrosini, Bowman, \& Collier, 2010), and, while more cases are required of graduate students, undergraduate courses also require students to read, analyze, and prepare oral and written reports using cases. The pedagogy of case teaching has been researched most extensively at the graduate level. We investigate the use of cases in undergraduate classes by evaluating the factors influencing the degree of students' acceptance of cases.

Case teaching in business education started in 1920 at the Harvard Business School Jackson, 1926; Charan, 1976; Shugan, 2006). In his address to the Tenth Annual Meeting of the American Association of University Instructors of Accounting, Jackson (1926) refers to the case method as "nothing more or less that an attempt to find a better way of teaching than we had before known" (p. 108). Today, the case method stands as a major pedagogy in business education (Mesny, 2013) despite criticism by scholars. (Argyris (1980), for instance, questions the ability of the case method to foster the double-loop learning that management requires. Shugan (2006) claims that the case method negatively impacts faculty research resources and impedes the dissemination of research results in the classroom). However, the theory behind the case method is still under construction (Burgoyne \& Mumford, 2001), perhaps due to the difficulty of establishing a valid relationship between the case method and the performance of students later in their careers as managers (Mesny, 2013). Researchers need to find alternative ways to test the use of the case method. Such an alternative is proposed in this study.

Christensen and Carlile (2009) argue that faculty who categorize a course by its attributes in terms of lecture-based vs. case-based are hypothesizing that one method represents a better way to convey theory and are thus helping to build a theory that has not yet coalesced. The authors define theory building (i.e., descriptive theory) as comprising three steps: the development of constructs through careful observation, description, and measurement of phenomena; the categorization by attributes of the phenomena or development of frameworks; and the measurement of correlations between attributes and outcomes. Our study contributes to the descriptive theory of the case method: we propose constructs, present a framework, and provide statistical tests. The main purpose of this study is to develop constructs with which to evaluate the factors influencing the degree of students' acceptance of cases. Specifically, we propose a framework for the degree of student acceptance of case teaching and statistically test it on business administration undergraduates at a private university in Mexico.

\section{THEORETICAL FRAMEWORK}

\section{Literature review}

The case method, traditionally entrenched in graduate programs, has extended to undergraduate curricula (Bruner, Gup, Nunnally, \& Pettit, 1999; Mesny, 2013). To be accredited, business schools need to offer learning objectives for their students. The Association to Advance Collegiate Schools of Business (AACSB) guidelines require universities to develop measurable goals. Some universities have adopted goals for undergraduates that case studies could help with (Rose \& Delaney, 2007; Kester, 2011). For example, the goal of thinking critically and creatively includes applying elements of critical thinking, identifying options and novel solutions, and comparing among multiple points of view. Case teaching promotes these goals since students must learn to analyze complex, noisy problems while considering multiple viewpoints. However, this characteristic often intentionally creates uncertainty, ambiguity, complexity, and diversity, which can be costly and difficult to manage (Booth, Bowie, Jordan, \& Ripplin, 2000). This becomes especially challenging for undergraduates, who lack business experience and are less tolerant of complexity and uncertainty. Indeed, Bruner et al. (1999) argue that what works with the case method for teaching graduate students may or may not work for teaching undergraduates. To provide some context, we next present studies, focused on both the graduate and undergraduate levels that have looked at the pros and cons of case teaching. This is followed by a literature review on students' attitudes toward case teaching.

Böcker (1987) found, after surveying graduate students in a marketing planning and control class, that case teaching was more effective than lecturing. Kooskora (2002) described the use of the case method in graduate ethics classes and suggested how instructors could use cases more effectively. Gonglewski and Helm (2010) found that cases were an effective tool. Their study included interviews with faculty and students over a two-year period about international business, foreign languages, and culture. Halvorson, Crittenden, and Pitt (2011) and Pitt, Crittenden, Plangger, and Halvorson (2012) used Second Life to create a virtual case study classroom successfully in a marketing class. Prat (2012) looked at perceived and actual student learning (performance) along with student satisfaction and participation among graduate information systems students. The study found that student satisfaction was positively correlated with participation in class case discussions, as was student participation and performance. The literature on cases in graduate education seems to concur that the case method is an effective teaching tool across business disciplines. 
Studies on case use in undergraduate education are rare (Booth et al., 2000). Banning (2003) found that the use of cases increased students' tolerance of ambiguity, a critical attribute of future decision makers. Bazan and Dugal (2014) looked at undergraduate student perceptions of group case work in strategic management classes, finding that students considered group case presentations as effective ways to learn. Doran, Healy, McCutcheon, and O'Callaghan (2011) studied the use of cases in accounting classes, finding that case studies could be successful but that, unless the case discussion was highly structured, it was difficult to elicit participation from students. Harper, Lamb, and Buffington (2008) examined the effectiveness of case teaching in a capstone information management course, finding widespread satisfaction with the case study approach. Some authors have suggested combining lectures and cases for undergraduates instead of using cases intensively. Moore (1999) found that finance undergraduate students learned equally well through cases and lectures, but preferred lectures. Kester (2011) also suggested using a combination of cases and lectures, emphasizing that undergraduates usually lack business experience and that lecturing builds an organizational frame of reference that helps students to contextualize cases. Overall, cases are accepted by undergraduates, and their use increases students' tolerance of ambiguity; but instructors need to consider that a highly structured discussion is necessary for cases to be effective and that combining cases with lectures may be advisable.

Research concerning student attitudes comes closest to research on student acceptance of cases, which we measure in this study. Student attitudes are discussed primarily as part of assessment studies. For example, Diamond (1998) noted that students' attitudes could influence what they learned. If students are hostile to a subject or method, like case teaching, learning could suffer unless attitudes are changed. In this case, the instructor might need to explain to students why he/she has chosen to use case studies, even though the case may not have a right answer (or may have multiple answers). Gardiner (1996), in studying the characteristics of lecture teaching, found that lectures tended to focus on low-level factual material and involved low student participation even when questions were asked. Gardiner also found that discussion was more effective for retaining information, transferring knowledge to other applications, problem solving, and changing attitudes. Shulman, Luechauer, and Shulman (1996) combined a meta-cognitive map with a portfolio assignment, whereby the instructor prepares a preliminary map showing learning objectives, specific learning outcomes, and how the learning in the assignment is classified according to Bloom's Taxonomy (i.e., recall, understand, apply, analyze, synthesize, evaluate), and students choose the methods by which they will demonstrate their mastery of the learning objectives. Students performed better when they were involved in the assessment process. This result supports the use of cases, more student-oriented than lecturing, to increase student feelings of ownership and motivation. The literature also discusses the relationship between students and professors in case discussions. Barnes, Christensen, and Hansen (1994) listed four principles for discussion teaching (creating a partnership between teachers and students, building a learning community, forging an alliance with students, and dual competency for instructors - managing content and process). They concluded that the instructor can strongly influence student attitudes by the way discussions are conducted in the classroom.

\section{Constructs and framework}

We propose a framework in which the degree of students' acceptance of cases depends on the selection of cases (selection), the teaching atmosphere (atmosphere), type and level of courses (type and level), training in the case method (training), faculty preconceptions about cases (preconception), level of faculty expertise (expertise), and intensity of use (intensity). Figure 1 depicts the framework. Next, we present studies that support these constructs.

Bruner et al. (1999) discussed the "most prominent aspects of using the case method of instruction at the undergraduate level" (p. 114). They suggested that the degree of success with the use of cases depends on how the cases are selected (selection), how cases are used in the classroom and the teaching style (atmosphere), and the type and level of the course for which the cases are used. Furthermore, they emphasized that the careful selection of cases is vitally important, especially for undergraduates: "The elements of designing a case course differ little between graduate and undergraduate levels. The primary method of adjusting the course for level of its content is the selection of cases" (p. 116). Charan (1976) and Andersen and Schiano (2014) also emphasized selection as a main determinant of case course design depending on the audience. More specifically, Gitman, Lewis, and Yates (1987) suggested that selection depends upon three key parameters: cognitive educational objectives, course level, and case complexity. Ambrosini et al. (2010) suggested the source of cases as an important determinant of selection.

The instructor's role, an element of atmosphere, has been described as that of a "coach" (Gitman et al., 1987) or "partner" 
(Healy \& McCutcheon, 2010). In that role, instructors are more active in conducting the class but allow students to participate more than they would in a typical lecture class. Gitman et al. (1987) caution that, if this role is not properly assumed, the class might be poorly executed, and the discussion is highly likely to go off-track or become too wide-ranging. This might occur because undergraduates lack the business experience that graduate students usually have. Healy and McCutcheon
(2010) classified teaching styles by dividing case teachers into controllers, facilitators, and partners, finding that only partners used cases with the explicit intention of fostering critical thinking and personal development. The authors concluded that cases can facilitate critical thinking, but that their effectiveness depends on the teaching style of the instructor. Thus, the attributes of the instructors teaching the cases are key determinants of atmosphere.

Figure 1. Framework for students'acceptance of cases



Proper training is one of the main ways to learn the craft of case discussion facilitation (Gill, 2011), thus reducing the risk that cases will amount merely to the illustration of theories (Foster \& Carboni, 2009) when taught by instructors who do not fully understand the philosophy behind cases. Writing cases is considered to be part of the teaching-learning process. According to Mesny (2013), instructor training should emphasize the affinity between teaching cases and researching cases, and reaffirm the usefulness of the philosophy behind them. Furthermore, institutions joining case collections such as the European Case Clearing House are required to certify professional quality standards (Ambrosini et al., 2010), for which training is key.

Böcker (1987) found that motivation enhanced learning that applies knowledge and skills, but not when learning simply reproduced knowledge and skills. He concluded that motivation positively affected the case method as compared to lecturing. The author considered motivation as "a prerequisite for any cognitive process" (Böcker, 1987, p. 66). We use preconception as a proxy for motivation. Finally, case teaching requires instructors to spend more time preparing a case class than they would spend on lecturing, and requires more student time to solve the cases. In Böcker (1987), the question of teaching efficiency remained open for future research.
To proxy for teaching efficiency in the context of the case method, we use intensity, defined as the amount of time instructors spend preparing a case and the length of the cases they use.

\section{METHODS AND MODEL}

We use both quantitative and qualitative methods. Data were collected through an online survey among business school instructors in a Mexican private university and interviews with a subset of the sample. In Mexico, Business Administration undergraduate programs in private universities tend to emphasize a practical and realistic approach over a theoretical one. In an attempt to pursue their goals, those universities retain a considerable portion of instructors who are practitioners and invited adjunct professors. Given their closeness to firms, those instructors tend to find the case method an attractive teaching tool. Case studies are widely used in MBA programs in Mexico and are familiar to most of the instructors in our sample, all of whom hold a master's or a PhD degree.

Prior to the survey, a pilot questionnaire was completed by 25 instructors who attended a presentation about the case method 
delivered by a representative of the Harvard Latin American Case Consortium from Harvard Business School Publishing (HBSP), who was visiting the university. (This university has been a member of this consortium for more than 10 years; membership allows professors full access to most teaching materials available in the HBSP collection). Preliminary analysis of the pilot study and content extracted from interviews with experts on the case method helped with fine-tuning the final questionnaire (available upon request), which included a statement on the objective of the study and a definition of a case, as a validation check for our object of study. During the interviews with experts, we validated what respondents understood to be a case, with responses delimitating cases as written documents related to firms' real situations, usually involving decision making issues, providing tools for the development of either practical tools for bringing theory into practice and/or developing soft skills (throughout the discussions and students' teamwork). Our conceptualization of cases is consistent with that of Harvardtype cases, which immerse students in realistic business situations, are usually written from the point of view of top management, and include class discussion intended to stimulate the development of students' critical thinking skills (Andersen \& Schiano, 2014). Ninetyone instructors completed the survey, representing a $48 \%$ response rate. We use these data to conduct factor analysis and regression.

The factor analysis identified clusters of latent variables that capture the attributes of the case method. Thus, the set of questions in the survey was reduced to a smaller set of factors or constructs. We tested these constructs using OLS regression, according to the model below:

$$
\begin{aligned}
& \text { Acceptance_perception }_{i}=\alpha_{0}+\alpha_{1} \text { selection }_{i}+ \\
& \alpha_{2} \text { training }+\alpha_{3} \text { preconception }_{i}+\alpha_{4} \text { intensity }_{i}+ \\
& \alpha_{5} \text { type }_{i}+\alpha_{6} \text { expertise }_{i}+\varepsilon_{i},
\end{aligned}
$$

where Acceptance_perception measures faculty perceptions of the degree of students' acceptance of cases. The proxy is the faculty's response to the question “According to your previous experience teaching cases, how would you evaluate students' level of acceptance of cases?" We measure instructor perceptions of the degree of students' acceptance of cases rather than students' acceptance directly. While this approach has potential limitations, we consider acceptance perception to be relevant because it captures instructors' observations about the success of the case method, which is supported by student teaching evaluations.

Selection, training, preconception, and intensity, are scales calculated using the variables extracted from the factor analysis (discussed in the following section). Type is a dichotomous variable set to one if the instructor teaches a qualitative course and zero otherwise. Similarly, expertise is a variable set to one for faculty who are experts on the case method.

In addition, we interviewed 15 instructors from the sample who, according to the department chairs, were experts in the case method. Each interview lasted one to two hours. This subsample was balanced, with seven instructors teaching quantitative courses such as finance and eight instructors of qualitative courses. The qualitative method used in this study was considered a two-round modified Delphi technique (Covino \& Iwanicki [1996] used a two-round modified Delphi in research on teaching effectiveness). According to Dalkey and Helmer (1963), Helmer (1967), and Hsu and Sandford (2007), the purpose of this technique is to obtain the most reliable consensus from among a group of experts by following the first round of questioning with a controlled feedback process. In the Delphi technique, experts do not interact with each other; rather, in subsequent rounds, they are asked to think again about the problem at hand and change their responses and provide additional insights. This is done by providing the experts with descriptive statistics about responses from previous rounds or with considerations suggested as being potentially relevant by another (anonymous) respondent. Opinions tend to converge as experts are allowed to reconsider their responses while obtaining feedback. However, consensus may not occur; instead, two "schools of opinion" may emerge. In any case, the Delphi method serves the purpose of "crystallizing the reasoning process that might lead to one or several positions on an issue and thus help to clarify the issue even in the absence of consensus" (Helmer, 1967, p. 9).

In this study, during the first round, all experts were individually interviewed on issues related to the use of cases. Specifically, we asked experts questions related to the definition and conceptualization of a case, the objectives of the case method, factors that incentivize or detract from the use of cases, case selection, and teaching atmosphere. Based on the responses, the researchers created lists of case method attributes, classified according to construct. For instance, on questions related to attributes of instructors teaching cases, the experts said instructors needed to have the ability to control the group in terms of discipline, respect, and harmony during the case discussion. According to respondents, instructors also needed to tolerate uncertainty concerning the direction of the discussion, new or disruptive ideas, and even the lack of good ideas during the discussion. In the second round, instructors were provided with lists of attributes and were asked to rank them in order of relevance. The researchers considered that attributes ranked by at least $50 \%$ of experts had achieved a considerable level of consensus. Attributes 
of instructors, attributes of the teaching process, and attributes of evaluation comprise the construct atmosphere. We also report in this study qualitative responses of level and selection. Other responses from the qualitative part of this study are not reported but served as a basis for improving our questionnaire.

\section{RESULTS}

\section{Factor analysis}

We conducted principal factor analysis on the (10) questions with interval value responses. The Kaiser-Meyer-Olkin measure verified the sampling adequacy for factor analysis (KMO $=0.672)$. According to Kaiser (1974) and Hutcheson and Sofroniou (1999), KMO values above 0.5 are acceptable for sample adequacy.
Untabulated $\mathrm{KMO}$ values in this sample are consistently above 0.6 across individual items, with some values exceeding 0.7 .

Table 1 provides the factor loadings after matrix rotation, sorted by loading magnitude. Questions are clustered by factor. We called these factors preconception, training, and intensity, following our theoretical constructs. Factor 1 could represent the construct preconception, which captures instructors' beliefs regarding case teaching compared to traditional lecturing. Preconception includes responses to questions 3.1, 3.2, 3.3, and 3.4, which directly compare case teaching with lecturing (e.g., cases are more realistic, or cases represent higher intellectual challenges). In addition, question 1 , which refers to the number of cases instructors use during a course, also belongs to the first factor. This is consistent with the possibility that the stronger instructors' beliefs are about the efficacy of cases, the more cases will be used in their courses. Preconception explains $24.1 \%$ of the variance.

Table 1. Exploratory factor analysis for the attributes of the case method questionnaire

\begin{tabular}{|c|c|c|c|}
\hline Short description of question & \multicolumn{3}{|c|}{ Factor } \\
\hline Cases are better accepted by students (3.4) & 0.853 & 0.031 & -0.063 \\
\hline Cases are more practical (3.2) & 0.591 & 0.124 & -0.091 \\
\hline Cases are more realistic (3.1) & 0.424 & -0.215 & 0.089 \\
\hline Cases represent higher intellectual challenge (3.3) & 0.350 & -0.306 & 0.194 \\
\hline Training on the case method (11) & 0.182 & 0.788 & 0.047 \\
\hline Self-perception of preparedness to teach cases (12) & 0.018 & 0.547 & -0.035 \\
\hline Eigenvalue & 2.410 & 1.978 & 1.138 \\
\hline Variance explained & 0.241 & 0.198 & 0.114 \\
\hline
\end{tabular}

Note: Extraction method = principal axis factoring. Rotation method = Oblimin with Kaiser normalization. For the pattern matrix rotation converged in 8 iterations. Number of question in brackets (questionnaire available upon request).

The second factor, which explains $19.8 \%$ of the variance, relates to training. Question 11 is directly related to the formal training instructors have received on the case method, question 12 addresses instructors' self-perception of preparedness for teaching cases, and question 9 relates to the extent of teaching note usage, which should be positively correlated with the level of faculty training or expertise. The last factor, explaining $11.4 \%$ of the variance, is intensity. This factor comes from questions
5 and 10, which refer to the number of hours instructors spend preparing a case to teach and to the number of pages per case. In other words, this construct captures the degree of instructors' commitment, proxied by how intense they are in terms of the amount of resources they spend in the teaching process. Collectively, the three factors explain $55.3 \%$ of the variance, and all have eigenvalues above 1.0, the cutoff value usually used for latent factor extraction. 
Regarding the reliability of the internal consistency of the scales, we estimated the inter-item correlations for the constructs, obtaining 0.278 for preconception, 0.376 for training, and 0.270 for intensity. These values fall within the optimal range according to Briggs and Cheek (1986), who suggested the use of these statistics instead of Cronbach's alphas for scales with fewer than 10 items. In terms of content validity, we considered the procedure proposed by Rossiter (2002), which "relies on logical arguments, and the concurrence of experts, based usually on open-ended input from pre-interviews with raters... having a comprehensive definition of what the construct is" (p. 308). Table 2 provides the three constructs from the factor analysis, along with their items, their respective scales, means, standard deviations, and coefficients of variation. Table 2 also presents selection, which uses categorical variables from questions related to case length, the language used in the case, whether the case had discussion questions, whether the case had simulations, and the sources used by the instructors to choose the cases. Type is a binary variable set to 1 for qualitative classes. Acceptance_perception is the dependent variable in the regression analysis, with the other constructs acting as explanatory variables.

Table 2. Constructs and items

\begin{tabular}{|c|c|c|c|c|c|c|}
\hline Construct & Short description of question & $\begin{array}{l}\text { Question } \\
\text { number }\end{array}$ & Scale & Mean & St. Dev. & $\begin{array}{l}\text { Coefficient } \\
\text { of variation }\end{array}$ \\
\hline \multirow{5}{*}{ Preconception } & Number of cases per semester & 1 & 1 to 3 & 1.43 & 0.70 & 0.49 \\
\hline & Cases are more realistic & 3.1 & 1 to 4 & 3.87 & 0.42 & 0.11 \\
\hline & Cases are more practical & 3.2 & 1 to 4 & 3.78 & 0.59 & 0.16 \\
\hline & Cases represent higher intellectual challenge & $3 \cdot 3$ & 1 to 4 & $3 \cdot 56$ & 0.61 & 0.17 \\
\hline & Cases are better accepted by students & $3 \cdot 4$ & 1 to 4 & $3 \cdot 30$ & 0.76 & 0.23 \\
\hline \multirow{2}{*}{ Intensity } & Hours of preparation per case & 5 & 1 to 4 & 2.46 & 0.74 & 0.30 \\
\hline & Number of pages per case & 10 & 1 to 3 & 1.78 & 0.81 & 0.45 \\
\hline \multirow{3}{*}{ Training } & Use of teaching note & 9 & 1 to 3 & 2.18 & 0.77 & 0.35 \\
\hline & Training on the case method & 11 & 1 to 4 & 2.75 & 1.03 & 0.37 \\
\hline & Self-perception of preparedness to teach cases & 12 & 1 to 2 & 1.79 & 0.41 & 0.23 \\
\hline \multirow{5}{*}{ Selection } & Length of case & 7.1 & Categorical & 1.90 & 0.93 & 0.49 \\
\hline & Language of case & 7.2 & Categorical & 2.12 & 0.90 & 0.43 \\
\hline & Discussion questions in the case & $7 \cdot 3$ & Categorical & 2.25 & 0.85 & 0.38 \\
\hline & Whether case has simulations & $7 \cdot 4$ & Categorical & 1.86 & 0.35 & 0.19 \\
\hline & Sources & 8 & Categorical & 2.78 & 0.79 & 0.28 \\
\hline Type & Qualitative or quantitative course & 2 & Binary & 0.62 & 0.49 & 0.78 \\
\hline $\begin{array}{l}\text { Acceptance_ } \\
\text { perception }\end{array}$ & $\begin{array}{l}\text { Faculty perception on the degree on students' } \\
\text { acceptance of the case method }\end{array}$ & 4 & 1 to 4 & 3.15 & 0.68 & 0.21 \\
\hline
\end{tabular}

Note: Questionnaire available upon request.

\section{Descriptive statistics on individual items and factors}

We discuss the descriptive statistics, from Table 2, after the factor analysis because the latter facilitates the discussion due to the categorization of items by construct. We also discuss selected categorical variables from Table 2 . Overall, the discussion that follows is consistent with the findings in the factor analysis section and the regression analysis, to be shown later.

Regarding preconception, instructors concur that the use of cases, as compared to that of traditional lectures, allows for more realistic and practical sessions, and implies a higher intellectual challenge for students (items within this construct have relatively high means, and their coefficients of variation are the lowest across constructs in Table 2). Nevertheless, instructors are not as optimistic about cases being better accepted than lectures (e.g., 3.30 mean compared to values around 3.6, 3.7, and 3.8 for the rest of the items in this construct). Instructors might teach cases mainly because they perceive the case method as a highly attractive teaching tool in terms of the benefits for business education and to a lesser extent because students prefer it to traditional lecturing. This is consistent with the finding by Moore (1999). 
Items forming part of selection have the highest coefficients of variation across the constructs, implying less uniformity in the way instructors select case materials. Figure 2 depicts the frequency distributions of the items constituting selection (we refer to items as "attributes of the construct" hereafter). For length of cases, $48 \%$ of instructors prefer brief cases, and $38 \%$ are indifferent about this attribute. Of the sample, $35 \%$ of faculty prefer cases written in Spanish. Most instructors are indifferent as to whether cases contain discussion questions. Similarly, instructors are generally indifferent as to whether cases have simulations. Finally, $47 \%$ of instructors choose HBSP and similar case collections such as Darden Business School Publishing, among others, as their sources for cases, and $18 \%$ write the cases they teach. We consider these sources to be of higher quality than the other options (e.g., free cases from the internet and textbooks or magazines). Regarding selection, then, faculty prefer brief cases, cases in Spanish, and rely primarily on HBSP-type publishers.

Figure 3 presents the attributes of training. The first graph shows that only $40 \%$ of faculty use teaching notes. The second graph shows that $25 \%$ have received formal training in the case method, which may partially explain the low usage of teaching notes. Surprisingly, most instructors (79\%) believe they are prepared to teach cases. Taken in combination, formal training is lacking, but almost half of the faculty received informal training through exposure to the case method as students in their MBA programs (see second graph in Figure 3), and instructors believe this is sufficient preparation to teach cases.

Figure 4 provides the attributes of intensity. Most faculty (51\%) spend one to three hours preparing a case to teach, and $34 \%$ spend three to six hours; these figures match estimates in Ross, Engelseth, Kindred, and Shelman (2015). Moreover, 46\% of instructors prefer cases of between one to five pages long, and $31 \%$ prefer cases of six to 10 pages. This is consistent with their preference for brief cases. The definitions of brief- and regular-length cases might be arbitrary, but, to establish a point of reference, we searched the HBSP collection and found that onethird of all cases labeled "HBS Brief Cases" had no more than 10 pages, and virtually all brief cases contained no more than 15 . (We searched the HBSP collection online in September 2014; 117 cases were considered "HBS Brief Cases," with 40 containing one to 10 pages, 80 containing 11 to 15 pages, and only 10 with more than 16). The preference for brief cases represents a challenge for instructors teaching undergraduates since brief published cases are scarce.

Table 3 provides the correlation coefficients for the questions used in the factor analysis. The low correlations suggest that multicollinearity problems are not a concern. Questions 5 and
$10\left(Q_{5}\right.$ and $\left.Q_{10}\right)$, relating to intensity, are positively correlated, with a rho of 0.26 , and statistically significant at $5 \%$. Questions about preconception (Q1, Q3.1., Q3.2., Q3.3., and Q3.4.) correlate negatively with hours of preparation per case (column $Q_{5}$ ) and positively with the number of pages per case (Q10). This implies that the more instructors support the case method, the higher the number of pages per case, but the less time they spend preparing a case to teach. Responses in the qualitative part of this study confirmed that supporters of case teaching are more knowledgeable about the method and therefore spend less time preparing a case to teach.

Table 4, which provides the factor correlations rather than individual item correlations, summarizes the relationships. Preconception is positively related to intensity: the more instructors support the case method, the more resources they spend, despite the tradeoff between length of cases and hours of preparation mentioned above. Preconception is negatively related to training: the more instructors support the case method, the more they realize their lack of preparation. Training and intensity relate positively, suggesting that heavy users might be a subset of instructors who are better-trained in the case method. Indeed, during the interviews, we found that expert instructors were intense users of cases and were better trained in the case method. Our interpretation of these relationships is the following. The case method is an attractive mode of teaching, especially in a private business school where realistic, practical education is emphasized, and instructors are eager to adopt it, though they realize that some training beyond their previous exposure as MBA students is necessary. Furthermore, the findings suggest that training in the case method encourages heavier use of cases.

\section{Regression analysis}

Table 5 provides regression results using acceptance_perception as the dependent variable and the constructs from Table 2 as explanatory variables. For preconception, intensity, and training, we used a scale adding up the scores of the corresponding items. For selection, we chose length of case (dummy for brief cases; Selection_brief in Table 5), language (when the language in which the case is written matters for the selection; Selection language), and high-quality sources (i.e., cases from HBSP and similar publishers; Selection_source) to include in the models, as these were the relevant variables based on the previous discussion. Type is a binary variable for qualitative courses, and expertise is a dummy variable for instructors expert in the case method. 
Figure 2. Attributes of selection

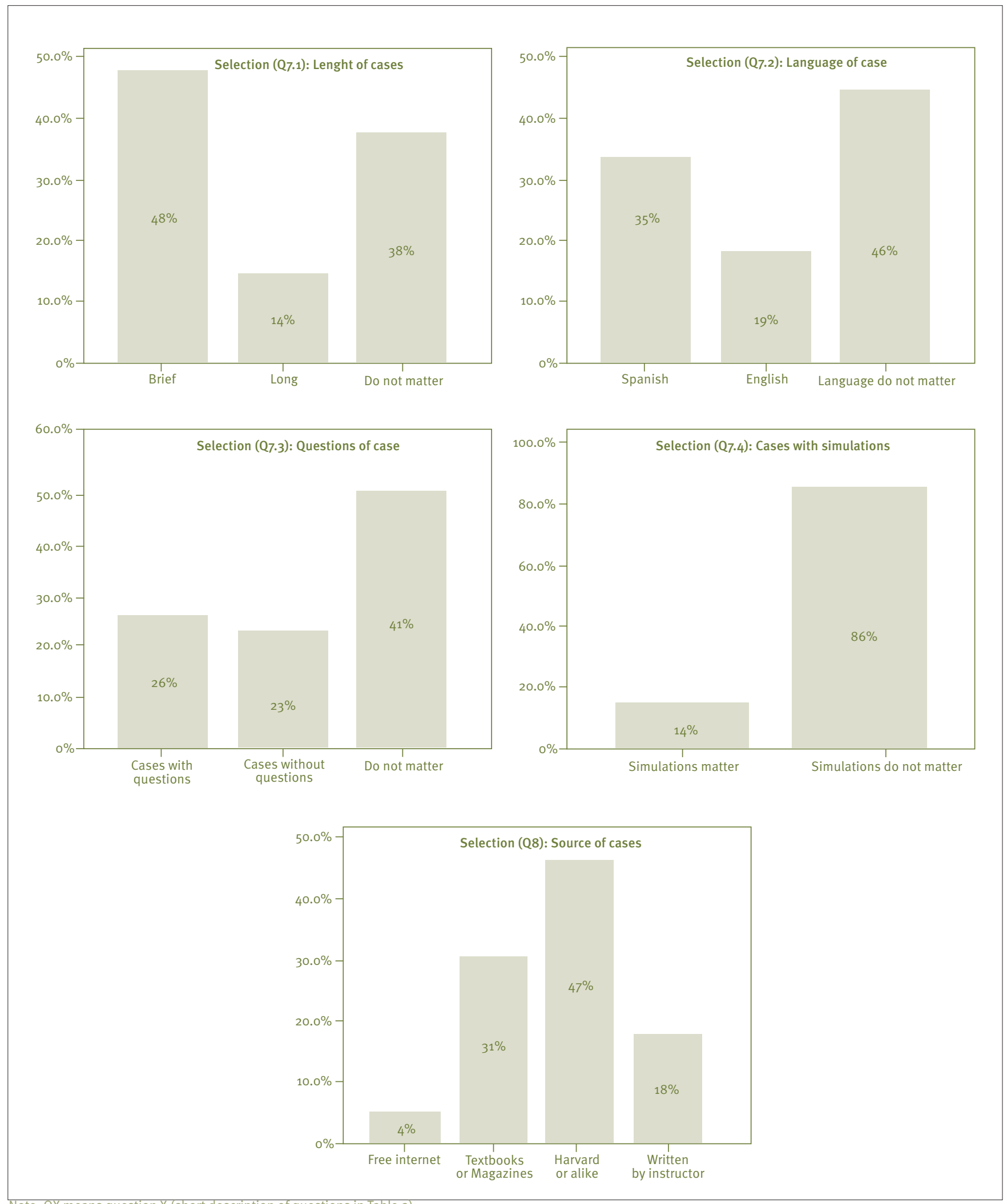

Note: QX means question X (short description of questions in Table 2). 
Figure 3. Attributes of training

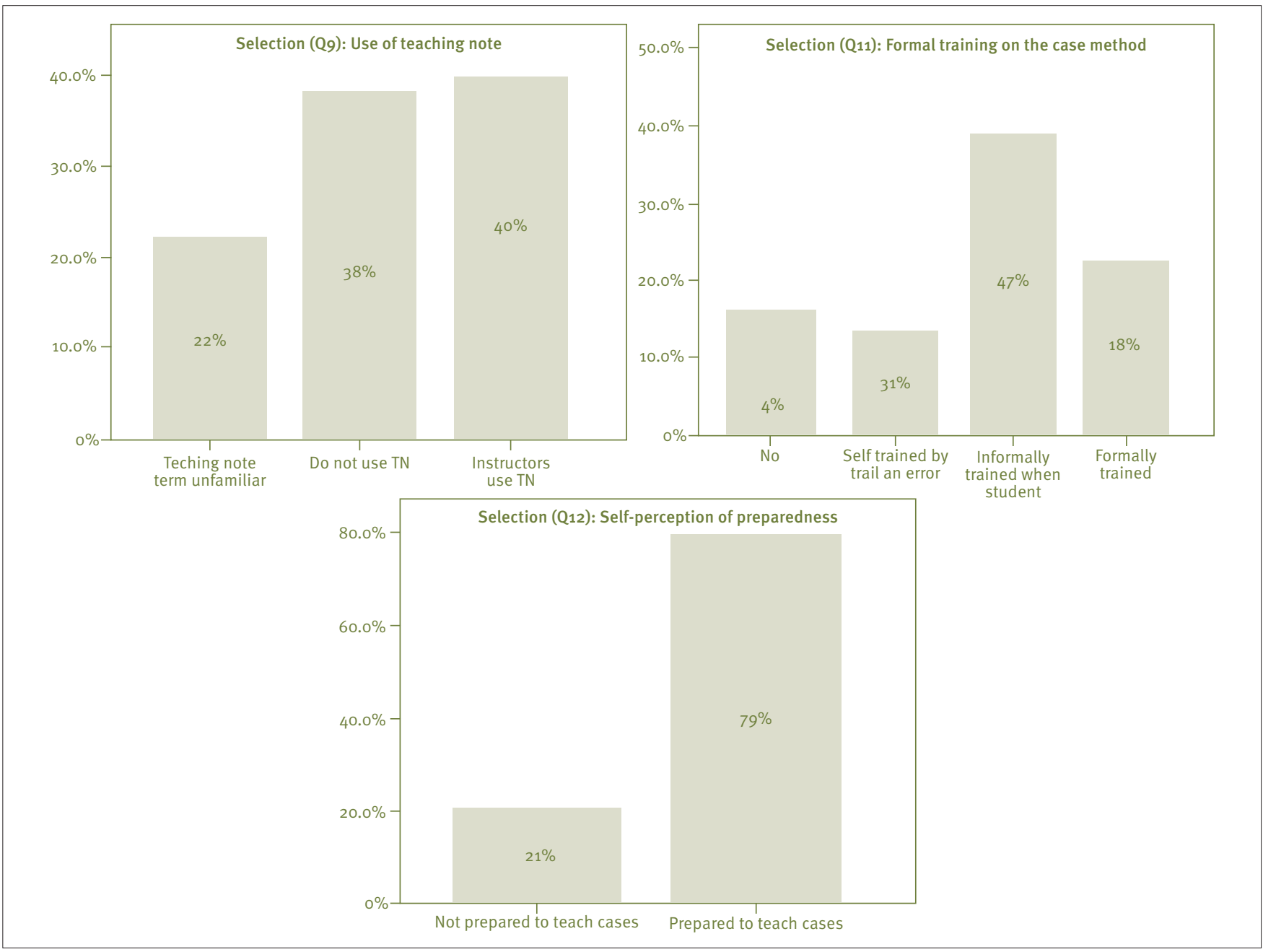

Note: QX means question X (short description of questions in Table 2).

\section{Figure 4. Attributes of intensity}



Note: QX means question X (short description of questions in Table 2). 
ARTICLES | THE USE OF CASE STUDIES IN UNDERGRADUATE BUSINESS ADMINISTRATION

Carlos J. 0. Trejo-Pech | Susan White

Table 3. Pearson correlation coefficients

\begin{tabular}{c|c|c|c|c|c|c|c|c|c|c}
\hline & Q1 & Q3.1 & Q3.2 & Q3.3 & Q3.4 & Q5 & Q10 & Q9 & Q11 & Q12 \\
\hline Q1 & & 0.109 & 0.194 & 0.234 & 0.361 & -0.112 & 0.103 & 0.101 & 0.059 & 0.044 \\
\hline Q3.1 & 0.195 & & 0.267 & 0.256 & 0.404 & -0.130 & 0.101 & -0.182 & -0.108 & -0.136 \\
\hline Q3.2 & 0.061 & 0.016 & & 0.146 & 0.473 & -0.179 & 0.062 & -0.047 & 0.163 & -0.031 \\
\hline Q3.3 & 0.030 & 0.020 & 0.124 & & 0.340 & -0.124 & 0.138 & -0.188 & -0.163 & -0.165 \\
\hline Q3.4 & 0.002 & 0.000 & 0.000 & 0.003 & & -0.192 & 0.045 & -0.051 & 0.028 & -0.061 \\
\hline Q5 & 0.186 & 0.151 & 0.077 & 0.163 & 0.063 & & 0.260 & 0.221 & 0.332 & 0.165 \\
\hline Q10 & 0.207 & 0.211 & 0.312 & 0.136 & 0.360 & 0.018 & & 0.272 & 0.190 & 0.067 \\
\hline Q9 & 0.212 & 0.074 & 0.356 & 0.067 & 0.344 & 0.039 & 0.014 & & 0.385 & 0.300 \\
\hline Q11 & 0.321 & 0.196 & 0.098 & 0.097 & 0.413 & 0.003 & 0.065 & 0.001 & 0.008 & 0.000 \\
\hline Q12 & 0.364 & 0.139 & 0.403 & 0.095 & 0.315 & 0.095 & 0.299 & 0.008 \\
\hline
\end{tabular}

Note: Correlation coefficients in the top half and significance level in the bottom half. QX means question X (short description of questions in Table 2).

Table 4. Factor correlations

\begin{tabular}{l|c|c|c}
\hline & Preconception & Training & Intensity \\
\hline Preconception & 1.000 & -0.177 & 0.094 \\
\hline Training & -0.177 & 1.000 & 0.192 \\
\hline Intensity & 0.094 & 0.192 & 1.000 \\
\hline
\end{tabular}

Table 5 . Regression results

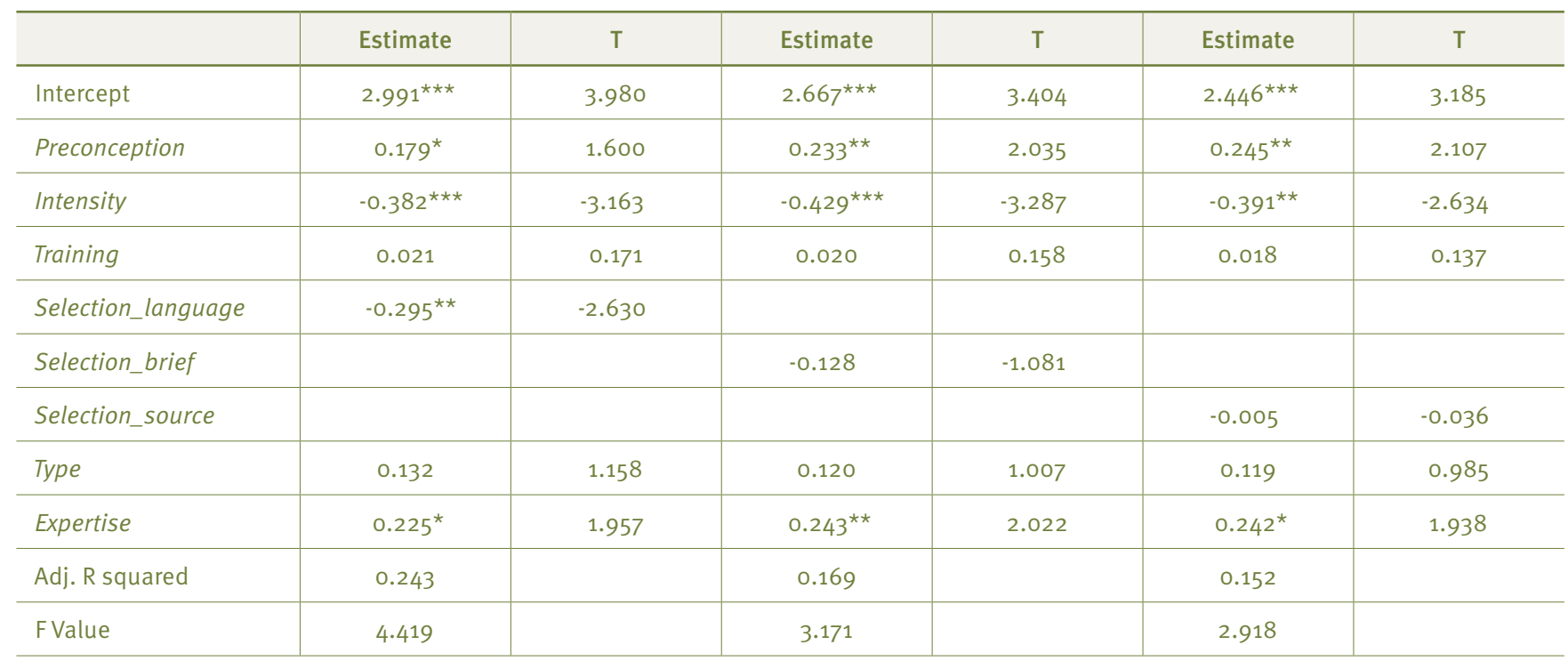

***, **, and * indicate statistical significance at the $1 \%, 5 \%$, and $10 \%$ levels respectively.

The model explains $24.3 \%$ of the variation according to the adjusted $\mathrm{R}$ squared. The estimate for preconception is positive and statistically significant at $5 \%$ and $10 \%$ across models. Instructors' beliefs regarding the case method as a mode of teaching superior to lecturing contribute positively to the degree of students' acceptance of cases, proxied by the perceptions of instructors. 
Intensity is negative and statistically significant at $1 \%$ for two models and at $5 \%$ for one. The more resources instructors expend in terms of number of pages per case and number of hours of preparation, the more detrimental the impact on the degree of student acceptance: too many resources negatively affect the output. It is possible that intense instructors, given the amount of resources they expend in the learning process, expect higher student acceptance than what they observe in the classroom.

Regarding selection, the language in which cases are written matters for these instructors: Selection_language is negative and statistically significant at $1 \%$. Instructors for whom language matters (those who prefer cases in Spanish or English, compared to instructors for whom language is irrelevant) perceive lower levels of student acceptance. As shown in the descriptive statistics section, most of the faculty in this sample prefers cases in Spanish. This result implies that instructors who are indifferent to case language find that cases are better accepted by students. This could be relevant for instructors and schools in non-English speaking countries: the ability to teach cases in English could become an advantage in terms of student acceptance because most high-quality cases are written in English. The other two proxies for cases selection, Selection_brief and Selection_source, are not statistically significant.

Training tends to be positive but is not statistically significant. However, a closely related estimate, the dummy variable expertise, indicates that faculty expertise positively affects acceptance levels. Since the interviews confirmed, as expected, that experts are better trained in the case method than is the average sample instructor, training in the case method is relevant. Finally, whether a class is quantitative or qualitative makes no difference to the level of acceptance by students, as type is not statistically significant.

As we report the standardized betas in Table 5 , the relative importance of the explanatory variables can be compared directly by looking at the magnitudes of the coefficients. For instance, a one standard deviation increase in intensity would reduce students' level of acceptance by 0.382 standard deviations. The next section, on the qualitative analysis, completes the discussion of the constructs, focusing on level and atmosphere. Further discussion on selection is also provided.

\section{Qualitative analysis}

Level

About $73 \%$ of the experts interviewed teach cases primarily to juniors and seniors. The experts commented that, to a lesser extent, they use cases when teaching freshmen or sophomores.
The consensus among the faculty was that senior students show higher interest and acceptance of the case method, while freshmen and sophomores sometimes show resistance. This is consistent with the finding in Kester et al. (2008), who surveyed students from many countries outside the US. According to experts in our study, freshmen and sophomores find it difficult to coordinate work in teams, which is required in most case courses; they also cannot yet contextualize a typical business problem, as cases require and thus show little commitment to or interest in solving a case (relative to learning from a lecture). In contrast, seniors may have accumulated enough of a technical business background to be able to properly contextualize problems stated in cases, tolerate the uncertainty that cases present, and propose feasible solutions.

\section{Atmosphere}

In trying to understand the elements of atmosphere, we focused on three sets of attributes: (1) the attributes of instructors, (2) the attributes of the teaching process, and (3) the attributes of evaluation. Exhibit 1 provides all these attributes, with asterisks on those ranked the most relevant by at least $50 \%$ of the experts.

The top attributes of instructors that create an appropriate atmosphere are listed in Panel A. At the top of the list, $91 \%$ of experts ranked as relevant the instructor's flexibility in adjusting the teaching plan during class based on the technical background of the class, and in adjusting the pace and direction of the discussion (flexibility, in Panel A). Second, $64 \%$ considered relevant the ability to control the group in terms of discipline, respect, and harmony during the case discussion (ability to control the group). Third, tolerance of uncertainty concerning the discussion's direction and of new or disruptive ideas, and even the lack of good ideas during the discussion, was ranked as relevant by $60 \%$. Finally, about $55 \%$ of experts ranked as desirable a high level of instructor preference for the case method relative to other teaching modes. Other attributes mentioned during the interviews, but not ranked as most relevant, are listed in alphabetical order in Panel A.

Concerning the attributes of the teaching process, or the relevant steps followed when teaching cases (Panel B), experts ranked most highly a thorough reading of the case (82\%), followed by the use of audio or video related to the case $(60 \%)$. The assignment of written homework was ranked as important by $58 \%$. Discussion of the case among student team members was considered relevant by $55 \%$. Finally, $55 \%$ considered the discussion of the case with the full class to be relevant. Additional attributes are provided in alphabetical order. 


\section{Exhibit 1. Construct atmosphere}

Panel A: Attributes of instructors

(1) Flexibility*

(2) Ability to control the group*

(3) Tolerance*

(4) High level of preference for the case method*

Acting skills

Analytical skills

Dynamism

Extroversion

Time dedicated to prepare the case previous to the discussion

Panel B: Attributes of the teaching process

(1) Thorough reading of the case*

(2) The use of audios or videos related to the case*

(3) The assignment of written homework*

(4) The discussion of the case among team members*

(5) The discussion of the case with the complete class*

Closing remarks by the instructor with a solution to the case

Lecturing on the theoretical topics related to the case

The assessment with the complete group of alternative solutions

The assignment of roles (e.g., a team represents the production department, a second team marketing)

The assignment of reading theory related to the case

The discussion or search of additional information, available on the internet, related to the case or company

Panel C: Attributes of evaluation

(1) The quality of participation in class*

(2) The appropriate detection of the issue in the case*

(3) The correct detection of relevant facts in the case*

(4) The feasibility, correctness, and realism of the propose solution*

Some evidence that the student read the case

The level of creativity of the proposed solution

The quality of the analysis

Note: Attributes with an asterisk are those ranked as most relevant by at least $50 \%$ of experts during the second round of Delphi. The numbers that precede the attributes indicate their rank according to experts.
Regarding evaluation attributes, $90 \%$ of experts ranked as most important (1) the quality of participation in class, followed by (2) the appropriate detection of the issue in the case, (3) the correct detection of relevant facts in the case, and (4) the feasibility, correctness, and practicality of the proposed solution. There was no consensus among experts about specific details concerning evaluation, such as percentage of the total grade, methods of evaluation, or what constituted good participation. However, several faculty members stated their preference for more weight placed on quizzes.

\section{Selection}

We further assessed selection because the attributes "brief cases" and "high quality cases" are important for faculty according to the surveys, but these variables were not statistically significant in the regression (regression analysis section). All of the expert faculty ranked a match between the objectives of the case and those of the teaching as the top attribute when selecting cases (see Exhibit 2); 60\% chose length of cases, with a preference for brief ones; $60 \%$ also chose the case's level of complexity, which needed to be suitable for the course level. A well-written case was also chosen by $60 \%$ of expert faculty as relevant when selecting cases. Finally, about half of the experts ranked the availability of teaching notes as important when selecting cases. These responses add insights to the quantitative results. For instance, the language in which a case is written is an important attribute for expert faculty but is not as relevant as the teaching objectives of the case, the length of cases, the attractiveness of the case, and the availability of teaching notes.

\section{Exhibit 2. Construct selection}

(1) A match between objectives of the case and the teaching objectives*

(2) The length of cases (brief cases preferred)*

(2) The complexity level of case is in accordance to course level ${ }^{\star}$

(2) A well-written case (e.g., logical structure, attractive narrative)*

(3) Teaching note availability*

Availability of complementary information or tools (e.g., simulations, readings)

Familiarity of instructor with the company or industry

Language in which the case is written

The topic of the case is of current importance

Note: Attributes with an asterisk are those ranked as most relevant by at least $50 \%$ of experts during the second round of Delphi. The numbers that precede the attributes indicate their rank according to experts. 


\section{CONCLUSIONS AND IMPLICATIONS}

This study has just begun to explore the use and acceptance of case studies in undergraduate courses. We develop constructs in order to evaluate the factors influencing the degree of students' acceptance of cases. In our proposed framework, students' acceptance is affected by the case selection, intensity of faculty use, course type and level, level of instructor expertise, teaching atmosphere, and the faculty's beliefs about the usefulness of the case method. We survey instructors and use factor analysis to validate several constructs and regression analysis to test our proposed model. We complement the quantitative analysis by interviewing a subset of the sample and employing a two-round modified Delphi technique. Scholars might find the proposed framework of interest and crossvalidate it using different samples to improve the factor structure. The results might also be useful for administrators in business schools using or planning to use the case method.

Instructors' beliefs about the case method as a mode of teaching superior to lecturing contribute positively to students' level of case acceptance. Thus, efforts to educate faculty about the case method might enhance students' degree of acceptance. Concerning case selection, we find that faculty members prefer brief cases. This preference for shorter cases may indicate that undergraduates (and their instructors) prefer more focused cases with less ambiguity. The availability of brief cases represents a challenge for faculty, however, because case collections primarily publish cases of regular length. HBSP has recently increased its number of brief cases, and some publishers such as CASE Journal by Emerald have recently called for the publication of compact cases. Additional attributes of case selection such as usage of teaching notes and the language in which the case is written are discussed in this study.

We find that case usage intensity negatively affects case acceptance among students: the more resources instructors spend in terms of number of pages per case and number of hours of preparation, the more detrimental to the level of acceptance by students. On the other hand, we find a positive intensity effect among the subset of expert faculty. Being an expert instructor positively and significantly affects students' acceptance of cases. Expert faculty recommend special attention and adjustments to the case method when cases are taught to freshmen and sophomores. A combination of short cases and lectures may work better in basic undergraduate courses. Finally, we find that whether a class is quantitative or qualitative makes no difference to the level of student acceptance.

There are several limitations to this study, providing opportunities for future research. Since students were not surveyed, we measured faculty perceptions of the degree of students' acceptance of cases, rather than the degree of students' actual acceptance. While this approach has potential limitations (for instance, the faculty's enthusiasm for, or preconception with, the case method may influence their assessment of students' degree of acceptance), the dependent variable used in this study remains relevant because it measures instructors' observations about the success of the case method, which is supported by student course evaluations. Thus, instructors are able to perceive the degree of students' acceptance as the semester progresses. Future research may survey students or use students' course evaluations to validate or contradict this analysis. In addition, while this study focuses on instructors at a Mexican university, where the language in which the cases are written and/or taught is clearly an important factor, it could be duplicated at US universities and in other countries to determine whether instructors and students elsewhere have the same preferences and attitudes.

\section{REFERENCES}

Andersen, E., \& Schiano, B. (2014). Teaching with cases: A practical guide. Boston, USA: Harvard Business Review Press.

Ambrosini, V., Bowman, C., \& Collier, N. (2010). Using teaching case studies for management research. Strategic Organization, 8(3), 206 229. doi: $10.1177 / 1476127010374254$

Argyris, C. (1980). Some limitations of the case method: Experiences in a management development program. The Academy of Management Review, 5(2), 291-298.

Banning, K. C. (2003). The effect of the case method on tolerance for ambiguity. Journal of Management Education, 27(5), 556-567. doi: $10.1177 / 1052562903252652$

Barnes, L. B, Christensen, C. R, \& Hansen, A. J. (1994). Teaching and the case method. Boston, USA: Harvard Business School Press.

Bazan, S., \& Dugal, M. (2014). Surveying student perceptions of group case assignments in strategic management classes. Academy of Business Research Journal, 1, 44-52.

Böcker, F. (1987). Is case teaching more effective than lecture teaching in business administration? An exploratory analysis. Interfaces, 17(5), 64-71. doi: http://dx.doi.org/10.1287/inte.17.5.64

Booth, C., Bowie, S., Jordan, J., \& Ripplin, A. (2000). The use of the case method in large and diverse undergraduate business programmes: Problems and issues. European Case Clearing House and the Foundation for Management Education. Retrieved from http://www. thecasecentre.org/files/downloads/research/RPo302M.pdf.

Briggs, S. R., \& Cheek, J. M. (1986). The role of factor analysis in the development and evaluation of personality scales. Journal of Personality, 54, 106-148. doi: 10.1111/j.1467-6494.1986.tboo391.x 
Bruner, R., Gup, B., Nunnally, B., \& Pettit, L. (1999). Teaching with cases to graduate and undergraduate students. Financial Practice and Education (Fall/Winter), 111-119.

Burgoyne, J., \& Mumford, A. (2001). Learning from the case method, Report to the European Case Clearing House. ECCH. Bedford, UK, RPo301.

Charan, R. (1976). Techniques in teaching by the case method. The Academy of Management Review, 1(3), 116-123. doi: 10.5465/ AMR.1976.4400979

Christensen, C. M., \& Carlile, P. R. (2009). Course research: Using the case method to build and teach management theory. Academy of Management Learning \& Education, 8(2), 240-251. doi: 10.5465/ AMLE.2009.41788846

Covino, E. A., \& Iwanicki, E. F. (1996). Experienced teachers: Their constructs of effective teaching. Journal of Personnel Evaluation in Education, 10, 325-363. doi: 10.1007/BFo0125499

Dalkey, N., \& Helmer, O. (1963). An experimental application of the Delphi method to the use of experts. Management Science, 9(3), 458-467.

Diamond, R. (1998). Designing and assessing courses and curricula: A practical guide. San Francisco, USA: Jossey Bass.

Doran, J., Healy, M., McCutcheon, M., \& O’Callaghan, S. (2011). Adapting case-based teaching to large class settings: An action research approach. Accounting Education: An International Journal, 20(3), 245-263. doi:10.1080/09638180.2011.583742

Foster, P., \& Carboni, I. (2009). Using student-centered cases in the classroom. An action inquiry approach to leadership development. Journal of Management Education, 33, 676-698. doi: http://dx.doi.org/10.1177/1052562908328747

Gardiner, L. (1996). Redesigning higher education: Producing dramatic gains in student learning. Report 7. Washington, DC: Graduate School of Education and Human Development, George Washington University.

Gill, T. G. (2011). Informing with the case method: Guidelines for case method research, writing and facilitation. Santa Rosa, USA: Informing Science Press.

Gitman, L., Lewis, W. F., \& Yates, R. M. (1987). An approach for assessing, selecting, and using finance cases. Journal of Financial Education, 1(Fall), 65-68.

Gonglewski, M., \& Helm, A. (2010). An examination of business case methodology: Pedagogical synergies from two disciplines. Global Business Languages, 15, 17-31.

Halvorson, W., Crittenden, V., \& Pitt, L. (2011). Teaching cases in a virtual environment: When the traditional case classroom is problematic. Decision Sciences Journal of Innovative Education, 9(3), 485-492. doi: 10.1111/j.1540-4609.2011.00322.x

Harper, J., Lamb, S., \& Buffington, J. (2008). Effective use of case studies in the MIS capstone course through semi-formal collaborative teaching. Journal of Information Systems Education, 19(4), 411-418.

Healy, M., \& McCutcheon, M. (2010). Teaching with case studies: An empirical investigation of accounting lecturers' experiences. Accounting Education, 19(6), 555-567. doi: 10.1080/09639284.2010.501577
Helmer, O. (1967). Analysis of the future: The Delphi method. Paper No. 3558, Santa Monica: Rand Corporation.

Hsu, Ch., \& Sandford, B. (2007). The Delphi technique: Making sense of consensus. Practical Assessment, Research \& Evaluation, 12(10), 1-8.

Hutcheson, G., \& Sofroniou, N. (1999). The multivariate social scientist. London, UK: Sage.

Jackson, J. H. (1926). The case method. The Accounting Review, 1(1), 108-111.

Kaiser, H. (1974). An index of factorial simplicity. Psychometrika, 39, 31-36. doi: 10.1007/BFo2291575

Kester, G. W. (2011). Reflections on thirty years of using the case method to teach finance. Advances in Financial Education, 9, 62-80.

Kester, G. W., Anderson, M. A., Dean, R. A., Ding, D. K., Plessis, A., Hoover, S. A., \& Skully (2008). The views of students outside the United States on the case method of learning. Advances in Financial Education, 6, 147-160.

Kooskora, M. (2002). Using case studies in class. EBS Review, 15, 57-67.

Mesny, A. (2013). Taking stock of the century-long utilization of the case method in management education. Canadian Journal of Administrative Sciences, 30(1), 56-66. doi: 10.1002/cjas.1239

Moore, S. (1999). Cases vs. lectures: A comparison of learning outcomes in undergraduate principles of finance. Journal of Financial Education, 30(1), 37-49.

Pitt, N., Crittenden, V., Plangger, K., \& Halvorson, W. (2012). Case teaching in the age of technological sophistication. Journal of the Academy of Business Education, 13, 77-94.

Prat, N. (2012). Teaching information systems with cases: An exploratory study. Journal of Computer Information Systems, 52(3), 71-81.

Rose, J., \& Delaney, C. (2007). Case studies in real estate education: The new AACSB accreditation standards and a proposed case study in real estate management. Journal of Real Estate Practice and Education, 10(2), 175-186. doi: 10.5555/repe.10.2.w787461mxn336ru6

Ross, B., Engelseth, P., Kindred, N., \& Shelman, M. (2015). Development and use of "teaching cases." International Food and Agribusiness Management Association (IFAMA) Case Workshop. Minneapolis: IFAMA.

Rossiter, J. R. (2002). The C-OAR-SE procedure for scale development in marketing. International Journal of Research in Marketing, 19(2002), 305-335.

Shugan, S. (2006). Save Research-Abandon the case method of teaching. Marketing Science, 25(2), 109-115. doi:10.1287/ mksc.1060.0202

Shulman, G. M., Luechauer, D.L, \& C Shulman (1996). Assessment for learning empowerment: The meta-cognitive map. In T. W. Banta, J. P. Lund, K. E. Black, \& F.W. Oblander (Eds.), Assessment in practice: Putting principles to work on college campuses (pp. 281-285). San Francisco: Jossey Bass. 